\author{
Waadyslawa Szulakiewicz \\ (Toruń)
}

\title{
Historia wychowania w Uniwersytecie Mikołaja Kopernika
} (1945-2005)

\section{Uwagi wstępne}

Podejmując próbę przedstawienia i oceny współczesnej sytuacji historii oświaty i wychowania w poszczególnych ośrodkach akademickich nie sposób nie odnieść się do przeszłości. Inna bowiem jest obecna sytuacja historii wychowania w tych ośrodkach, w których można mówić o przejmowaniu zadań dydaktyczno-naukowych przez kolejne pokolenia oraz widoczna jest bardzo często kontynuacja kierunków badań. Inaczej historia wychowania rozwija się w ośrodkach, w których brak ciągłości, jeśli chodzi o problematykę zainteresowań naukowych, a także treści nauczania. Aby z perspektywy tradycji spojrzeć na toruńską historię oświaty i wychowania niezbędny jest powrót do jej początków.

Rozważania na powyższy temat mają na celu ukazanie ogólnych tendencji w rozwoju toruńskiej historii wychowania w latach 1945-2005. W szczególności koncentruję się na przedstawieniu osób zajmujących się historią wychowania tak w sensie prowadzenia badań naukowych w tym zakresie, jak i nauczania na poziomie uniwersyteckim ${ }^{1}$ oraz zarysowuję kwestię instytucjonalizacji.

\section{Historycy wychowania i przemiany w strukturze organizacyjnej toruńskiej historii wychowania lat 1945-2005}

W Uniwersytecie Toruńskim od samego początku organizowania struktur uczelni i poszczególnych wydziałów planowano powołanie katedry historii wychowania. Co więcej sam Stanisław Łempicki nie wykluczał przejścia do Torunia. Wiązało się to też z propozycją objęcia Katedry Historii Oświaty i Szkolnictwa w Toruniu. Nie będąc ostatecznie zdecydowanym na przyjęcie tej propozycji, Łempicki w liście (z 3 września 1945 r.) do swego przyjaciela, pierwszego rektora uczelni toruńskiej, Ludwika Kolankowskiego²,

\footnotetext{
${ }^{1} \mathrm{~W}$ artykule koncentrujemy się na pracownikach naukowo-dydaktycznych związanych $\mathrm{z}$ UMK przez dłuższy okres, pomijamy tu S. Wołoszyna i K. Kubika, jak też młodszych pracowników, których zainteresowania badawcze bliższe były innym dyscyplinom (patrz przypis 18).

${ }^{2}$ Kolankowski Ludwik (1882-1956) historyk, badacz dziejów Polski XV-XVI w., działacz polityczny. Studia historyczne na UL i w Berlinie, habilitacja na UJ w 1913 r. Był pełnomocnikiem Naczelnika Państwa do spraw powstajacego uniwersytetu w Wilnie, do 1936 jego profesorem, a w latach 1936-1939 profesorem UJK. W czasie II wojny światowej zorganizował akcję ratowania dzieł sztuki. Od 1945 r. prof. UMK i pierwszy rektor oraz dyr. biblioteki (1949-1955). Położył duże zasługi dla organizacji tej uczelni.
} 
(w którym polecał także swoich kolegów z UJK jako kandydatów do objęcia powstających katedr) napisał:

Ja może utrzymam się w Krakowie na katedrze literatury polskiej starszej. Jest to bardzo prawdopodobne. Decyzja zapadnie niedługo. W każdym razie i mnie nie skreślaj drogi Ludwiczku $\mathrm{z}$ listy toruńskiej przy katedrze historii oświaty i szkolnictwa lub literatury polskiej starszej"”.

Ponownie zamierzano powołać Katedrę Historii Oświaty i Wychowania w roku akademickim 1948/1949 w ramach Instytutu Historii, lecz na przeszkodzie stanęły trudności z pozyskiwaniem profesorów ${ }^{4}$.

Następnie w ramach projektów organizacji Instytutu Historii z roku 1948/1949 planowano kreowanie Katedry Historii Oświaty i Wychowania na Wydziale Humanistycznym. Jednak, jak wynika $\mathrm{z}$ dokumentów źródłowych, na przeszkodzie stanęły braki kadrowe. Pozyskanie wówczas specjalisty w tej dziedzinie (jak i w kilku innych) nie było sprawą łatwą. Jak łatwo zauważyć historię wychowania $\mathrm{w}$ pierwotnych zamysłach wiązano $\mathrm{z}$ historią, a nie z pedagogiką. Ostatecznie jednak osoby uprawiające historię wychowania wchodziły w skład najpierw Katedry Pedagogiki, a później Instytutu Pedagogiki i Psychologii.

Początki toruńskiej historii wychowania wiążą się z pracownikami przybyłymi ze Lwowa. Należą do nich Jadwiga Lechicka, Kazimierz Sośnicki, który został powołany na stanowisko kierownika Katedry Pedagogiki. Każda z wymienionych osób odegrała inną rolę w rozwoju tej dyscypliny. Można stwierdzić, że K. Sośnicki jako kierownik Katedry sprawował patronat nad seminariami z historii oświaty $\mathrm{i}$ wychowania. Natomiast od roku 1946 do 1965 wykłady i seminaria $\mathrm{z}$ historii wychowania prowadziła Jadwiga Lechicka ${ }^{5}$.

${ }^{3}$ Powstanie i pierwsze dziesięć lat UMK 1945-1956. Wybór źródel, wydała H. Duczkowska-Moraczewska, Toruń 1995, s. 41. List pisany z Krakowa. Jednak, jak powszechnie wiadomo, mający kłopoty zdrowotne S. Lempicki pozostał w Krakowie.

${ }^{4}$ B. Nadolski, Wydział Humanistyczny, w: Uniwersytet Mikolaja Kopernika 1945-1955, Warszawa 1957, s. 41.

${ }^{5}$ Lechicka Jadwiga (1898-1965). Urodziła się 16 października 1898 r. w Krukienicach k. Mościsk. Ojcem jej był Andrzej Lechicki - nauczyciel muzyki, matką Franciszka z Kudrewiczów. Szkołę powszechną i gimnazjum ukończyła w Samborze. W latach 1912-1914 pracowała w Związu Strzeleckim i Harcerskim. Uczestniczyła w obronie Lwowa. Świadectwo maturalne zdobyła w IV Gimnazjum Państwowym we Lwowie w 1920 r. Po czym (w latach 1920-1924) studiowała na UJK pod kierunkiem J. Ptaśnika, T. Modelskiego, A. Szelągowskiego, S. Zakrzewskiego. Studia te zakończyła stopniem doktora filozofii (1924), zaś w latach 1924-1928 studiowała geografię uzyskując magisterium. J. Lechicka była asystentką w Katedrze Historii Nowożytnej UJK kierowanej przez A. Szelągowskiego. W 1929 r. uzyskała Stypendium Funduszu Kultury Narodowej i wyjechała na studia archiwalne do Paryża, Nancy, Lunewil, Drezna, Wiednia i Gdańska. Materiały wykorzystała do pracy o S. Leszczyńskim. Po powrocie do kraju (1930) zamieszkała w Lodzi, gdzie objęła posadę wizytatora w okręgu szkolnym łódzkim. W dwa lata później przeniosła się do stolicy obejmując funkcje wizytatora. Od 1936 r. pracowała także w Gimnazjum im. J. Lelewela i im. J. Słowackiego jako nauczyciel geografii $\mathrm{i}$ historii. W czasie okupacji brała aktywny udzial $w$ tajnym nauczaniu. Zajmowała się akcją pomocy więźniom. W powstaniu warszawskim zniszczeniu uległy jej prace o S. Leszczyńskim. Po powstaniu warszawskim w 1944 r. wywieziono ją do Niemiec. W 1945 r. powróciła do kraju i objęla na krótko obowiązki adiunkta na UL. Od 1946 r. aż do śmierci związała się z Uniwersytetem Toruńskim. W 1947 r. habilitowała się z dydaktyki historii i historii nowożytnej, w 1951 objęła obowiązki docenta, a w 1957 mianowana została profesorem nadzwyczajnym. W latach 1954-1958 Lechicka była kolejno prodziekanem i dziekanem Wydziału Humanistycznego UMK. Lechicka była współorganizatorem Toruńskiego Oddziału PTH i prowadziła sekcję dydaktyczną. Była także aktywnym członkiem TNT. 
Jadwiga Lechicka wchodziła najpierw do składu osobowego Katedry Historii Kultury, której kierownikiem był Kazimierz Hartleb, zaś od 1951 r. do Zespołowej Katedry Historii Polski, a wreszcie w 1962 r. powierzono jej kierownictwo Katedry Historii Polski i Powszechnej XV-XVIII w. ${ }^{6}$ Wykładała historię oświaty i wychowania oraz dydaktykę historii i historię organizacji szkolnictwa. Początkowo seminarium z historii wychowania prowadziła wspólnie z K. Sośnickim, a od 1954 r. samodzielnie. Wiele zajęć z historii wychowania prowadziła bezpłatnie. Z kolei w Katedrze Pedagogiki pracował S. Wołoszyn (w latach 1945-1948) ${ }^{7}$ oraz od 1951 r. Bolesław Pleśniarski, a w latach 1956-1966 Kazimierz Kubik , związany jednak bardziej z WSP w Gdańsku, które było jego podstawowym w tym czasie miejscem pracy ${ }^{9}$.

W roku 1976 nastąpiły zmiany organizacyjne, gdyż Katedrę Pedagogiki UMK przekształcono w Instytut Pedagogiki i Psychologii, a w jego strukturze wyróżniono Zakład Historii i Teorii Wychowania pod kierunkiem B. Pleśniarskiego ${ }^{10}$, będącego jednocześnie

Jej związki z historią wychowania zarówno w sensie organizacyjnym, jak i naukowym ujawniły się przede wszystkim w okresie powojennym. Współpracowała z Pracownią Dziejów Oświaty PAN. Była autorką jednego z rozdziałów Historii wychowana pod red. Ł. Kurdybachy. Jej zainteresowania historią oświaty dotyczyły głównie okresu Oświecenia. Do najważniejszych prac, w których poruszała zagadnienia dziejów oświaty należy zaliczyć: Józef Wybicki - życie $i$ twórczosć, Toruń 1962; Kultura $i$ szkolnictwo w czasach saskich, w: Historia wychowania pod red. Ł. Kurdybachy, t. I, Warszawa 1965; Odglosy strajku szkolnego $w$ Galicji, Księga Pamiątkowa ZNP, 1930; Stosunki Uniwersytetu Krakowskiego $z$ Akademia Chetmińskg, Zapiski Historyczne, T. 29, 1964; Wybicki i Komisja Edukacji Narodowej, „Zapiski TNT”, T. XV, Z zagadnień Óswiecenia na Pomorzu, Toruń 1957; Źródła do dziejów Akademii Chetmińskiej (1386-1815), Archiwum Dziejów Oświaty T. II, oprac. J. Lechicka, Wrocław 1963. J. Lechicka zmarła po ciężkiej chorobie 20 IV 1965 w Chełmży koło Torunia, została pochowana w Jarosławiu. Patrz: A UMK sygn. K-11/22, H-33/12 - akta habilitacyjne, A Ut, Akta osobowe J. Lechickiej, nr 1518. Balcerowicz B., Jadwiga Lechicka - monografia bio- bibliograficzna, Toruń 1980; J. Kita, R. Stobiecki, Stownik biograficzny historyków tódzkich, Łódź 2000, s. 62-63; O. Nikonowicz, Lechicka Jadwiga -historyk, prof. UMK, w: Toruński Stownik Biograficzny, T. 1, Toruń 1998, s. 152-153, J. Serczyk, Jadwiga Lechicka (16 X 1898 20 IV 1965), „Kwartalnik Historyczny” 1965 z. 4; A. Tomczak, Jadwiga Lechicka jako pedagog i działacz społeczny, „Zapiski Historyczne” t. 31,1966 z. 4; J. Wójtowicz, Jadwiga Lechicka jako uczony, ibidem.

${ }^{6}$ Uniwersytet Mikołaja Kopernika 1945-1955, Warszawa 1957, s. 47-49 i 71.

${ }^{7}$ Źródła podają dwie daty czasu pracy S. Wołoszyna na UMK 1945-1948 (Uniwersytet Mikotaja Kopernika 1945-1955..., s. 71) i 1945-1951 (Pracownicy nauki i dydaktyki Uniwersytetu Mikołaja Kopernika 1945-1994. Materiały do biografii, pod red. S. Kalembki, Toruń 1995, s. 762). Z kolei w źródłach dotyczących Uniwersytetu im. Adama Mickiewicza jest informacja, iż S. Wołoszyn kierował Katedrą Pedagogiki w tym Uniwersytecie w latach 1950-1953 (W. Markiewicz, Dzieje Uniwersytetu im. A. Mickiewicza w latach 1945-1958, w: Dzieje Uniwersytetu im. A. Mickiewicza 1919-1969, Poznań 1972, s. 384).

${ }^{8}$ Pracownicy nauki i dydaktyki Uniwersytetu Mikołaja Kopernika 1945-1994. Materiaty do biografii..., s. 382-383. T. Wróblewska podaje, że pracował na UMK w latach 1959-1966. Patrz: T. Wróblewska, Życie i twórczość Profesora Kazimierza Kubika, w: Historia wychowania w XX wieku. Dorobek i perspektywy, pod red. T. Gumuły, J. Krasuskiego, S. Majewskiego, Kielce 1998, s.133.

${ }^{9}$ Pracownicy nauki i dydaktyki Uniwersytetu Mikołaja Kopernika 1945-1994. Materiaty do biografii..,, s. $382-383$.

${ }^{10}$ Bolesław Pleśniarski (1908-1987). Urodził się 17 września 1908 w Budzyniu, powiat Chodzież, wówczas województwo Poznańskie; zmarł 4 VI 1987 w Toruniu. Podczas okupacji B. Pleśniarski posługiwał się pseudonimem Leśniewski. W rodzinnej miejscowości ukończył szkołę powszechną (5 klas) w 1922 r., następnie w 1927 r. Państwowe Seminarium Nauczycielskie w Rogoźnie Wlkp. (5 klas), a w 1936 r. eksternistycznie Państwowe Gimnazjum św. Marii Magdaleny w Poznaniu. W latach 1936-39 i 1945-46 studiował na Uniwersytecie Poznańskim, na Wydziale Humanistycznym, gdzie uzyskał stopień magistra filozofii w zakresie pedagogiki. W roku 1932 ukończył Państwowy Wyższy Kurs Nauczycielski w Toruniu. W 1959 r. na 
dyrektorem Instytutu Pedagogiki i Psychologii. Zakładem tym od roku akademickiego1978/1979 kierował Zdzisław Dąbrowski, uczeń Ryszarda Wroczyńskiego i Romany Miller ${ }^{11}$. W zakładzie zajęcia dydaktyczne oraz badania nad przeszłością historyczno-oświatową prowadzili Eugeniusz Paruzel ${ }^{12}$ i Teresa Wróblewska. Pierwszy z wymienio-

UMK w Toruniu obronił pracę doktorską pt.: „Poglądy Wielkopolan na sprawy wychowawcze i oświatowe w świetle prasy Wielkiego Księstwa Poznańskiego 1815-1847”, przygotowaną pod kierunkiem S. Truchima. Z kolei w 1974 r. na podstawie pracy pt.: Wychowanie w Gwardii i Armii Ludowej przeprowadził przewód habilitacyjny. W roku 1951 rozpoczął pracę akademicką na UMK w Toruniu: najpierw jako asystent na UMK (1951-1954), potem w 1954-1956 jako adiunkt na UMK, a w latach 1956-1961 jako zastępca profesora na UMK Toruniu, w 1961-1968 pracował na etacie starszego wykładowcy na tymże Uniwersytecie, w 1968 r. został docentem etatowym UMK w Toruniu. W latach 1969-1976 pełnił obowiązki kierownika Katedry Pedagogiki Wydziału Humanistycznego UMK Toruń, a w latach 1976-1978 był kierownikiem Zakładu Historii i Teorii Wychowania. W 1978 r. jako profesor nadzwyczajny przeszedł na emeryturę. W latach 1983-1986 pracował na pół etatu jako profesor Instytutu Pedagogiki i Psychologii na UMK w Toruniu. Będąc nauczycielem akademickim na UMK w Toruniu, pracował również w WSP w Gdańsku (1960), a w latach 1974-77 w WSP w Olsztynie. Zainteresowania badawcze Bolesława Pleśniarskiego rozwinęly się w dwóch kierunkach: pedagogiki oraz historii oświaty i myśli pedagogicznej. Do najważniejszych prac z zakresu historii oświaty należą: Z regionalizmu wielkopolskiego, Oborniki 1938; Zarys historii laicyzacji oświaty $i$ wychowania w Polsce, Warszawa 1961; Poglqdy Wielkopolan na sprawy wychowawcze $i$ oświatowe $w$ świetle prasy Wielkiego Księstwa Poznańskiego 1815-1847, Wrocław 1962; Szkolnictwo departamentu bydgoskiego w okresie Księstwa Warszawskiego, Toruń 1965; Wychowanie w Gwardii i Armii Ludowej, Warszawa 1973; O racjonalizm i postęp. Z prac programowych i praktyki KEN, Warszawa 1973; Koncepcje oświaty powojennej w powojennej w programie polskiej konspiracji 1939-45, Warszawa 1982. Był również współautorem licznych prac: B. Pleśniarski, T. Wróblewska, Gimnazjum Polskie i Liceum Ogólnokształcquce w Kwidzynie (1937-1939, 1945-1977), Wrocław 1980; B. Pleśniarski, T. Wróblewska, J. Popowicz, Antoni Makarenko w szkole wyższej i materiały z konferencji makarenkowskiej w Toruniu, 24 IV 1974; Anton Semenowic Makarenko; red. B.Pleśniarski, Torun 1974; Ponadto był autorem publikacji: Zagadnienie postępu $i$ wychowania w piśmie "Rok" pod względem oświaty, przemystu $i$ wypadków czasowych (1843-1846), w: Studia i Materiaty do dziejów Wielkopolski i Pomorza, t. III, z. 1937; Laickie tradycje edukacji polskiej, w: „Chowanna”, z. 9/10 1960, s. 429 494; Walka "Wolnej Szkoty” o laicyzację wychowania „Przegląd Historyczno-Oświatowy”, $n r 4$ 1961, s. 459-469. Patrz: AUMK: Akta personalne, sygn. K-39N/42, H 117/11; Ankieta 1983; P. Kowalik, Wspomnienia o profesorze dr hab. B. Pleśniarskim (1912-1987), „Chowanna”, 1987 z. 4 s. 481-482; Pracownicy Nauki i Dydaktyki UMK 1945-1994 materiaty do biografii,..., s.549-550

${ }^{11}$ A. Paruzel, Instytut Pedagogiki i Psychologii, w: Uniwersytet Mikotaja Kopernika 1966-1970, T. I, pod red. J. Bełkota, Toruń 1992, s. 117.

${ }^{12}$ Eugeniusz Jakub Paruzel (1949-2004), historyk oświaty, absolwent Uniwersytetu Wrocławskiego. Urodził się 12 maja 1949 r. w Miasteczku Śląskim koło Tarnowskich Gór jako syn Leona i Gertrudy, w rodzinie robotniczej. Po ukończeniu Liceum Ogólnokształcącego w Tarnowskich Górach (1967 r.) rozpoczął naukę w Seminarium Nauczycielskim w Katowicach. Następnie zapisał się na studia pedagogiczne w Uniwersytecie Wrocławskim. Ukończył je w 1974 r., uzyskując magisterium na podstawie pracy pt. „Poglądy pedagogiczne Zygmunta Balickiego" napisanej pod kierunkiem prof. Mirosławy Chamcówny. Jeszcze w czasie studiów skierował pismo do dziekana Wydziału Humanistycznego UMK z prośbą o przyjęcie na staż w Instytucie Pedagogiki i Psychologii. Prośba poparta została pozytywną opinią promotora pracy magisterskiej M. Chamcówny. W roku akademickim 1974/ 75 E. Paruzel zostaje zatrudniony na UMK na stanowisku asystenta - staźysty w Zakładzie Historii i Teorii Wychowania. Kierownikiem Katedry Pedagogiki, w której mieścił się zakład był doc. B. Pleśniarski. W następnych latach przechodził kolejne stopnie awansu. W roku 1982 uzyskuje stopień doktora przedkładając pracę pt. „Oświata pozaszkolna na Pomorzu w okresie II Rzeczypospolitej - organizacja, założenia, formy". Promotorem pracy był Bolesław Pleśniarski, recenzentem Jerzy Danielewicz.

W roku 1996 na podstawie pracy Ideat wychowawczy Narodowej Demokracji i próby jego realizacji na przełomie $X I X$ i $X X$ w. (1993), uzyskuje stopień doktora habilitowanego. Habilitacja zostaje zatwierdzona w 1996 r. W roku 1996 odchodzi z pracy na UMK, nie otrzymując dalszego przedłużenia. Od tego roku 
nych historyków wychowania był uczniem prof. Mirosławy Chamcówny. T. Wróblewska zaś, uczennicą prof. K. Kubika zatrudniona w 1975 w UMK, gdzie pracowała do 1989 r. ${ }^{13}$

Od momentu pierwszych zamysłów utworzenia jednostki zajmującej się historią wychowania do praktycznej realizacji przedsięwzięcia musiało minąć ponad 30 lat. Bo oto samodzielna jednostka pod nazwą Zakład Historii Oświaty i Wychowania powstał w 1984 r., a jego kierownikiem został powołany ówczesny dyrektor Instytutu Pedagogiki i Psychologii Jerzy Danielewicz ${ }^{14}$. Trzeba jednak zaznaczyć, że podstawowy obszar zainteresowań naukowych J. Danielewicza dotyczył historii Polski i historii powszechnej XIX i XX w., nie zaś historii oświaty i wychowania ${ }^{15}$. Kierował zakładem do roku 1991,

pracuje w różnych szkołach wyższych m.in. prywatnych. Jego zainteresowania naukowe koncentrują się wokół dziejów oświaty pozaszkolnej 2 połowy XIX wieku i XX wieku. Opublikował m.in.: Biblioteki oświatowe na Pomorzu Gdańskim w okresie II Rzeczypospolitej, „Roczniki Biblioteki Narodowej” T. 86, 1993; Ideat wychowawczy Narodowej Demokracji i próby jego realizacji na przełomie XIX i XX w., Toruń 1993; Instytut Pedagogiki i Psychologii, w: Uniwersytet Mikotaja Kopernika 1966-1980, pod red. J. Bełkota T. I, Toruń 1992 s. 116-123; Organizacja oświaty pozaszkolnej na Pomorzu w latach 1933-1939, AUNC, Nauki Hum.-Społ., z. 252, 1993. Źródła i opracowania: A UMK, Sygn. K-76 N/ 63, Pracownicy nauki i dydaktyki Uniwersytetu Mikotaja Kopernika 1945-1995. Materialy do biografii.., s. 530.

${ }^{13}$ Teresa Barbara Wróblewska (ur. w 1936 r.), historyk oświaty i wychowania, absolwentka Uniwersytetu Gdańskiego, magisterium (1968) i doktorat (1977), pod kierunkiem K. Kubika, habilitacja w 1988 r. w Uniwersytecie Poznańskim. Opublikowała m.in.: Uniwersytety Rzeszy w Poznaniu, Pradze i Strassburgu jako model hitlerowskiej szkoty wyższej na terytoriach okupowanych, Toruń 1984; Polskie organizacje na Pomorzu Gdańskim w latach 1871-1914, Warszawa 1989; współautorka: B. Pleśniarski, T. Wróblewska, Gimnazjum Polskie i Liceum Ogólnokształcące w Kwidzynie (1937-1939, 1945-1977), Wrocław 1980; B. Pleśniarski, T. Wróblewska, J. Popowicz, Antoni Makarenko w szkole wyższej i materialy z konferencji makarenkowskiej w Toruniu, 24 IV 1974. Patrz: Pracownicy nauki i dydaktyki Uniwersytetu Mikotaja Kopernika 1945-1995. Materialy do biografii, s.768.

${ }^{14}$ Jerzy Danielewicz ( 1921-1997). Studia wyższe odbył na Uniwersytecie Łódzkim (1949), tam także uzyskał stopień doktora (1954 ); habilitacja w Uniwersytecie Mikołaja Kopernika w Toruniu (na podstawie pracy: „Ruchy rewolucyjne na ziemiach Polski południowo-wschodniej w latach 1918-1923”, recenzenci: prof. dr Ż. Kormanowa, prof. dr J. Dutkiewicz); tytuł profesora nadzwyczajnego uzyskał w roku 1976; tytuł profesora zwyczajnego w 1991 r. J. Danielewicz w latach 1948-1954 pracował w Uniwersytecie Lódzkim; następnie w latach 1954-1961 w Uniwersytecie Marii Curie-Skłodowskiej w Lublinie. Kolejnymi miejscami pracy były: Wyższa Szkoła Pedagogiczna w Gdańsku (1961-1969), Wyższa Szkoła Nauczycielska w Bydgoszczy (1969-71) i Wyższa Szkoła Pedagogiczna w Bydgoszczy (od 1991). Z Uniwersytetem Mikołaja Kopernika zwiazany był w latach 1971-1991, jako docent w Zakładzie Historii Powszechnej i Polski XIX i XX wieku, Instytut Historii i Archiwistyki (1971-1975), profesor nadzwyczajny w Zakładzie Historii Powszechnej i Polski XIX i XX wieku (1976-1983), kierownik Zakładu Języków Słowiańskich (1981-1984), Instytut Historii i Archiwistyki (do 1984), dyrektor Instytutu Pedagogiki i Psychologii (1984-1987), kierownik Zakładu Historii Oświaty i Wychowania (1984-1991) w 1991 przeszedł na emeryturę. Zainteresowania badawcze J. Danielewicza dotyczyły: historii Polski i powszechnej XIX i XX wieku, historii historiografii oraz historii nauki. Ważniejsze publikacje: Historia Powszechna i Polski (1789-1870), skrypt dla studentów korespondencyjnych, Lódź 1950; Generat Józef Bem - sylwetka dowódcy, Warszawa 1951; Generat Ignacy Prądzyński 1792-1850, Warszawa 1954; Powstanie Ślqqskie 1919-1921 - skrypt, Warszawa 1959; Ruchy rewolucyjne na ziemiach Polski Poludniowo-Wschodniej w latach 1918-1923, Gdańsk 1964; Ruchy rewolucyjne na Lubelszczyźnie w latach 1918-1923, Lublin 1968; Materiały z dziejów szkolnictwa Ziemi Gdańskiej, Gdańsk 1968; Patrz: A UMK, Akta osobowe, sygn. K-55/9; Jerzy Danielewicz - pierwszy rektor Wyższej Szkoty Nauczycielskiej w Bydgoszczy, w: X lat WSN w Bydgoszczy, Bydgoszcz 1979, s. 29-30; Pracownicy Nauki i Dydaktyki UMK 1945-1994 - materialy do biografii, red. S. Kalembka, Toruń 1995, s. 157-158; K. Kwaśniewska, M. Rak, Naukowcy Bydgoszczy. Stownik biograficzny, Bydgoszcz 1997, s. 50-51.

${ }^{15} \mathrm{Na}$ dorobek J. Danielewicz z zakresu historii wychowania składają się drobne artykuły w wydawnictwach zbiorowych. 
czyli do przejścia na emeryturę. W 1991 r. w ramach przemian organizacyjnych w Instytucie Pedagogiki powstał Zakład Historii Wychowania i Myśli Społecznej, kierownictwo którego powierzono Andrzejowi Wojtasowi, historykowi, absolwentowi WSP w Krakowie $^{16}$. Po nim w roku 1996 kierownictwo zakładu przejął Witold Wojdyło, absolwent studiów historycznych na UMK, uczeń Władysława Lewandowskiego, historyka wojskowości ${ }^{17}$. Zakład funkcjonował przez 10 lat $^{18}$. W 2002 r. zakład ten został przemianowany na Zakład Historii Edukacji ${ }^{19}$ pod kierunkiem Władysławy Szulakiewicz ${ }^{20}$. Już nazewnictwo zakładów wskazuje poniekąd na zainteresowania naukowe osób je tworzących.

W sześćdziesięcioleciu toruńskiej historii wychowania można wyróżnić kilka kierunków badań. Przyjmując jako kryterium problematykę są to:

- Historia instytucji i organizacji oświatowych (B. Pleśniarski, E. Paruzel, T. Wróblewska),

- Dzieje oświaty pozaszkolnej (E. Paruzel),

- Biografistyka (W. Szulakiewicz, A. Wałęga),

- Historia myśli pedagogicznej i społeczno-oświatowej (W. Szulakiewicz, W. Wojdyło, A. Wojtas),

- Historiografia edukacyjna (W. Szulakiewicz).

Analizując dorobek twórczy toruńskich historyków oświaty i wychowania zauważa się duże zainteresowanie badaniami regionalnymi. Uprawiali je B. Pleśniarski, E. Paruzel, T. Wróblewska. Z kolei w okresie istnienia Zakładu Historii Wychowania i Myśli Społecznej, jego pracownicy w swoich badaniach naukowych poszukiwali politycznych

\footnotetext{
${ }^{16}$ Andrzej Wojtas, (ur. w 1942 r.) historyk, uczeń Józefa Buszki. Jego zainteresowania naukowe dotyczą historii ruchu ludowego i historii polskiej myśli politycznej. Z zakresu historii oświaty pod jego redakcją ukazała się Polityka a wychowanie. Szkice z historii wychowania spolecznego II Rzeczypospolitej, Toruń 1994.

${ }^{17}$ Witold Wojdyło ( ur. w 1947 r.) historyk myśli politycznej XIX i XX w. Pod redakcją W. Wojdyły ukazały się następujące publikacje dotyczące historii oświaty i myśli społeczno-pedagogicznej (będące pokłosiem konferencji naukowych): Wychowanie a polityka. Tradycje $i$ wspótczesność, red. W. Wojdyło i M. Strzelecki, Torun 1997; Wychowanie a polityka. Między wychowaniem narodowym a państwowym, Toruń 1999; Wychowanie a polityka. Mity i stereotypy w polskiej myśli spolecznej, Toruń 2000. Jest także autorem kilku artykułów zamieszczonych w wydawnictwach zbiorowych.

${ }^{18}$ W Zakładzie Historii Wychowania i Myśli Społecznej pracowali: mgr Katarzyna Kalinowska i dr Michał Strzelecki - obecnie związani z politologią: K. Kalinowska, pracuje w Instytucie Politologii UMK i M. Strzelecki w Instytucie Politologii Uniwersytetu im. Kazimierza Wielkiego w Bydgoszczy oraz mgr Jarosław Góralski i dr Adam Marszałek, obecnie dyrektor „Wydawnictwa Adam Marszałek".

${ }^{19}$ Biuletyn Prawny Uniwersytetu Kopernika nr 5, Toruń 8 lipca 2002 r., zarządzenie rektora 109, nr 35 z dnia 1 lipca 2002 r. Skład Zakładu Historii Edukacji do roku 2005 tworzyli doktoranci, w 2005 r. została zatrudniona dr Agnieszka Wałęga, absolwentka studiów historycznych i pedagogicznych oraz studiów doktoranckich w Instytucie Pedagogiki UMK. Jest autorką monografii: Życie $i$ działalność Wandy Szuman (1890-1994), Toruń 2005.

${ }^{20} \mathrm{Na}$ mój dorobek wydawniczy w okresie toruńskim składają się m.in.: I. Monografie: „Rozprawy z Dziejów Oświaty” (1958-2002). Studium z historii czasopisma, Toruń 2004, ss. 17; Historia oświaty $i$ wychowania w Polsce 1944-1956, Kraków 2006, ss. 33; II Redakcje: Źródla w badaniach naukowych historii edukacji, Toruń 2003, ss. 241; Acta Universitatis Nicolais Copernici-Pedagogika-Historia Wychowania, Toruń 2004, ss. 106 oraz ok. 30 artykułów zawartych w czasopismach i wydawnictwach zbiorowych.
} 
uwarunkowań rozwoju oświaty i myśli pedagogicznej ${ }^{21}$. W ostatnim pięcioleciu dominują badania nad historią myśli pedagogicznej i historiografia edukacyjną.

W omawianym okresie historycy wychowania wykładali ten przedmiot głównie dla studentów pedagogiki, z wyjątkiem lat, w których zwieszono nabór na studia pedagogiczne, tj. 1959-1973. Wówczas Katedrę przekształcono w jednostkę usługową, której zadaniem było przygotowanie studentów wszystkich wydziałów do pracy pedagogicznej. Każdorazowo treści programowe warunkowane były (co jest naturalną tendencją) zainteresowaniami naukowymi wykładowców.

\section{Uwagi końcowe}

Podejmując próbę ogólnego spojrzenia na sześćdziesiąt lat rozwoju toruńskiej historii wychowania można wyróżnić kilka cech charakterystycznych odnoszących się tak do prowadzonych badań naukowych, jak i osób tworzących środowisko tej dyscypliny. Trzeba podkreślić, że kierownictwo jednostek zajmujących się historią wychowania spoczywało w rękach historyków (J. Danielewicz, A. Wojtas, W. Wojdyło). Do roku 2002 wyjątkiem w gronie kierownictwa był B. Pleśniarski, którego zainteresowania naukowe i dorobek naukowy dotyczyły głównie historii wychowania, chociaż i pedagogiki. Dla większości wymienionych wcześniej kierowników jednostek skupiających badaczy przeszłości oświatowo-wychowawczej, historia wychowania stanowiła poboczny nurt zainteresowań. To nie pozostawało bez wpływu na kierunki prowadzonych badań, jak też treść zajęć dydaktycznych ${ }^{22}$. Podobnie jak w wielu innych uczelniach, a przede wszystkim wyższych szkołach pedagogicznych ${ }^{23}$, toruńska historia wychowania w latach 1976-1984 funkcjonowała w ramach jednego zakładu z teorią wychowania, od roku 1984 do 1991 historycy wychowania posiadali samodzielną jednostkę, a następnie na 10 lat pozostawała pod wpływem historii myśli społecznej i politycznej, w jednej jednostce naukowej. Obecną sytuację toruńskiej historii oświaty i wychowania, bezsprzecznie warunkuje dorobek i doświadczenia przeszłości tak w sensie naukowym, jak i dydaktycznym. Ciągła zmiana orientacji badawczych wynikających ze zmiany kierownictwa jednostek i składu osobowego nie była zapewne czynnikiem wpływającym pozytywnie i sprzyjającym stabilizacji tej dyscypliny. Widoczny jest brak przejmowania określonych zadań naukowo-badawczych $\mathrm{z}$ pokolenia na pokolenie, tak jak jest to $\mathrm{w}$ warszawskim

\footnotetext{
${ }^{21}$ Stwierdzenie to potwierdza tekst: M. Strzelecki, Polityka a wychowanie. Toruński ośrodek badań $w$ dziedzinie historii wychowania, „Biuletyn Historii Wychowania”1997, s. 60-61; M. Strzelecki, J. Góralski, Toruński ośrodek badań w dziedzinie historii wychowania (Zakład Historii Wychowania i Myśli Spolecznej), w: Historia wychowania w XX wieku. Dorobek i perspektywy, red. T. Gumuła, J. Krasuski, S. Majewski, Kielce 1995, s. 559-561.

${ }^{22}$ Patrz: Pedagogika UMK. Pakiet Informacyjny 2000/2001, Programy nauczania historii wychowania s. 49-52. W treściach programowych i doborze lektur akcent położony został na polityczne uwarunkowania rozwoju oświaty i wychowania.

${ }^{23}$ Patrz sprawozdania z poszczególnych ośrodków w „Biuletynie Historii Wychowania”, także W. Szulakiewicz, Historia wychowania 1995-2004. Srodowisko - kierunki badań - perspektywy rozwoju, ,Rocznik Pedagogiczny" t. 27, 2004, s. 59-76.
} 
i krakowskim ośrodku badań historyczno-oświatowych ${ }^{24}$. Trzeba jednak mieć świadomość, że rozwój historii oświaty i wychowania tak na UMK, jak i innych ośrodkach naukowych, uzależniony był $\mathrm{i}$ jest od zmieniających się tendencji $\mathrm{w}$ rozwoju nauk pedagogicznych.

${ }^{24} \mathrm{Na}$ ten temat: J. Dybiec, Historia wychowania w Uniwersytecie Jagiellońskim, w: Historia wychowania w XX wieku, s. 491-498; I. Szybiak, Katedra Historii Oświaty $i$ Wychowania (1953-2003), w: Wydziat Pedagogiczny Uniwersytetu Warszawskiego. Jubileusz pięćdziesięciolecia, red. J. Kamińska, Warszawa 2004, s. $183-226$. 